\title{
Relationship between foreign direct investments and economic aspect of sustainable development
}

\author{
Auob Alsayd \\ Phd. candidate \\ DOI: 10.29322/IJSRP.11.12.2021.p12051 \\ http://dx.doi.org/10.29322/IJSRP.11.12.2021.p12051
}

\begin{abstract}
Modern business environment imposes on countries that if want to achieve growth and development in the economy, they must first establish relations with the rest of the world. In addition to trade relations with the environment, countries must take into account investment flows, through which they will provide funds, knowledge, resources and more, if they want to follow the dynamics of the world market. One of the ways to invest in international capital movements is foreign direct investment. In addition to enabling significant effects on the economic growth of the country in which the funds are placed, they also enable a positive impact on the quality of life and the environment, the social sphere of life and others.

Sustainable development activities are reflected in the interrelationships that are realized between the care for the living world and the environment, with the economic, economic and social aspects that society, the individual, the state and ultimately the whole of humanity face. Sustainable development refers to all aspects of environmental protection, social development, environmental issues, economic and political spheres of life.
\end{abstract}

Index Terms- Modern. countries, economy, investment, environment.

\section{INTRODUCTION}

$\mathrm{T}_{\mathrm{i}}$ he effects of foreign direct investment are not only reflected in the inflow of fresh capital, but also in the transfer and implementation of new technological solutions, know-how, as well as organizational solutions. However, sometimes the effects of foreign direct investment on the economic development of host countries are not always at the expected level. In practice, there are cases where the resources of the host country are to be exploited exclusively through foreign investments. That is why it is important to take into account primarily the structure of foreign direct investments. Iimplementation of the basic postulates of sustainable development has been significantly reduced nowadays, largely due to the way in which the current process of globalization is managed.

What is perceived as the main problem in the part related to the possibility of applying environmentally friendly technologies, reducing waste and improving the situation in the field of environment, is the lack of coordinated relations between

\footnotetext{
1 Olgica Nestorović, Foreign direct investment as a factor of sustainable development of the Serbian economy, Faculty of

institutions supporting the globalization process, on the one hand, and environmental stakeholders, on the other hand. That is why the world leaders in the 21st century are faced with finding solutions for achieving better coordination between the institutions responsible for promoting economic growth and those dealing with the environmental consequences of economic activities.

As sustainable development basically has purpose to integrate environmental issues into the decision-making process in areas such as industry, agriculture, trade, energy and finance, in order to ensure certain environmental benefits through integration into all sectors. What is important to note in relation to the relationship between globalization and exploitation of natural resources is that it is not direct, but shaped by policies, institutions and certain processes at the local, regional and global levels.

1. Relationship between foreign direct investments and economic aspect of sustainable development

Foreign direct investment has a positive effect on the economic aspect of the country in which the funds are invested, in three ways.

The first way, refers to when there is a disparity between savings and investments as a consequence of the current account deficit, in which case the net inflow of foreign investments leads to an increase in the rate of domestic investment in the host country, as well as an increase in production.

The second way is related to the growing efficiency of the companies in which they invest funds. The efficiency of an existing or newly formed company can be achieved from two different sources, namely: economies of scale and, on the other hand, the reduction of inefficiencies. "In small countries, the use of economies of scale through domestic mergers and acquisitions is possible to a certain point, after which there is too much industrial concentration.

In contrast, productivity gains resulting from reduced inefficiencies do not depend on economies of scale. It lies in the transfer of the best experiences of merged companies, in the form of new management, knowledge and technology. Through these different channels, foreign direct investment can increase labor productivity, even when there are no new fixed investments, e.g. when foreign direct investment arises as a result of mergers and acquisitions."

The third way involves transfer of knowledge and technology, that is transferred to the merged company, to local

Economics in Kragujevac, University of Kragujevac, 2015, page 54 
companies. "This occurs in cases when the company hires local suppliers or sells semi-finished products to local companies. The existence of more efficient foreign-owned enterprises can encourage local competitors to innovate in order to survive in the market, thus increasing the quality, productivity and diversity of local producers 'products. This can start the process of consolidation and increase the economies of scale between local competitors, bringing with them the acquired knowledge. In this way, productivity in a local enterprise can be increased, even though it has not received foreign direct investment."

This type of investment provides the investor with the opportunity to strengthen its position in the market and thus influence the definition of the price of its products and services. "In the first two cases, the higher growth rate due to the increase in fixed investments and technology transfer to the merged company contributes to the private rate of return being the same as the social rate of return. This means that the company that invests is encouraged to choose the level of foreign direct investment that is optimal from a social point of view. In the case of the third channel, positive spillovers to surrounding companies mean that social returns are higher than private ones.

Foreign direct investments have the largest share in international investments at the end of the 20th century. The motives of the recipient of foreign direct investment are: the profit of a multinational company that is then taxed, the possibility of creating new jobs, the transfer of knowledge, technology and management skills, improving the quality of the workforce and human capital. Utilizing the comparative advantages of the host country with the investments of a foreign investor can be an important element for the penetration of domestic production on the world market.

Their role in avoiding the debt crisis is also important. Namely, foreign direct investments are of a longer-term character than numerous loans, without having to repay them, and sometimes the debt is exchanged for shares of a company from the debtor's country. They can also encourage the growth of production in domestic companies, improve management activities and improve human capital. In addition to benefits, foreign direct investment creates certain social costs such as ousting domestic companies from the market due to greater competition, distortions in the labor market, deterioration of the current account of the balance of payments if newly created companies import more than export or less reinvestment in foreign direct investment flows. , the impact of multinational companies on the country's economic policy or stability. "3

At the same time, in practice, there is "the possibility of pressure on the currency due to a significant inflow of foreign direct investment in a small country, which is unfavorable for those who borrow in foreign currency, as well as entities that are largely oriented to foreign trade. The remaining costs are the suspicion that economic growth will not be accelerated and that

\footnotetext{
${ }^{2}$ Ibid

3 Olgica Nestorović, Foreign direct investment as a factor of sustainable development of the Serbian economy, Faculty of Economics in Kragujevac, University of Kragujevac, 2015, page 54
}

This publication is licensed under Creative Commons Attribution CC BY. http://dx.doi.org/10.29322/IJSRP.11.12.2021.p12051 there will be a reduction in stock market activity because often a newly acquired company becomes part of a foreign owner. For that reason, it is necessary to take care that such investments do not incur higher costs than the benefits for the domestic economy. $" 4$

Foreign direct investments significantly contribute to the economic development of a country, however, how much of their contribution will actually be, largely depends on macroeconomic, institutional and financial factors. "The recipient of foreign direct investments has positive effects on income based on the profit of a multinational company that is taxed, on the basis of job creation, transfer of knowledge and new technologies, management skills, improvement of labor quality, etc." However, they also create certain social costs, such as ousting domestic companies from the market due to greater competition, labor market disturbances, deteriorating current account balances if start-ups import more than they export, the impact of multinational companies on economic policy or the country's stability.

Countries in transition have been forced to attract foreign capital in order to modernize the existing business environment and thus gain the conditions for stronger economic growth in the future. Utilizing the comparative advantages of the host country with the investments of a foreign investor can be an important element for the penetration of domestic production on the world market. "5 Also, their role in the debt crisis is of great importance.

\section{RELATIONSHIP BETWEEN FOREIGN DIRECT INVESTMENT AND THE SOCIAL ASPECT OF SUSTAINABLE DEVELOPMENT}

The economic differences that exist between social strata, ie economic inequalities, are primarily a consequence of differences between countries, including their developmental evolution, productivity and tradition, ie current economic and social policies. However, many individual inequalities in society arise due to a multitude of factors that cause differences in income from work

Thus, for example, the diversity of income from work is most affected by: the ability and skills of individuals, from physical and mental abilities to knowledge of how to make money, intensity of work, which depends on country to country and work tradition and culture, occupations, which it is mostly conditioned by technological progress and economic structure, other factors such as: family origin, belonging to ethnic or minority groups, a certain gender, age, culture, as well as individual personality traits.

In the age of mass communication, growing prosperity in one part of the population raises expectations for a better life everywhere. Indeed, the global revolution of rising expectations has been a major driving force for change in the last five decades. Namely, television carries images of luxury life in the metropolis and abroad, and as this growing awareness is not accompanied by

4 Oplotnik, T., J., (2006) "Some Macroeconomic Aspects of Foreign Direct Investment" in the collection: (Jovanović, Šević (ed. 9)

5 Olgica Nestorović, Foreign direct investment as a factor of sustainable development of the Serbian economy, Faculty of Economics in Kragujevac, University of Kragujevac, 2015, page 60 
growing opportunities, it leads to increased frustration, social tension and sustainability, violence, which expresses increasing incidents of violence in China and India, the two fastest growing economies in the world.

One of the essential elements of culture is that humanity is occupied with quantitative growth, and increasing consumption relative to the primary value represented by qualitative improvements derived from harmonious, fulfilling human relationships. It would mark a change and a more complete transition of humanity from a physical phase preoccupied with material to a vital phase of social competition in which the imperative is an enlightened and fulfilled way of life, a change that can best be characterized as a transition from preoccupation with protection to welfare."

\section{RELATIONSHIP BETWEEN FOREIGN DIRECT INVESTMENTS AND THE ENVIRONMENTAL ASPECT OF SUSTAINABLE DEVELOPMENT}

Ecology is a significant factor in international relations, which has a strong impact on product quality, price, distribution channels in international trade. In order for certain companies to build the best possible competitive advantage on the world market, it is necessary to respect environmental standards, ie a high awareness of respect for the natural environment. "Neither the first nor the second industrial revolution had a sense of the environment, the country was often ruthlessly exploited, and air and water, according to classical economic theory, were free goods. However, today, most experts understand that the mechanism of the traditional cost-based economy too narrowly defines the real price that society pays for the abuse of the human environment. "7

"Environmental regulations are the main tool that can internationalizs the costs of environmental protection through the economic activity of the company. Therefore, in order to attract foreign investment, developing country governments tend to endanger the environment through a relaxed attitude towards foreign investors or do not enforce regulations. As a result, companies are shifting their operations to those developing countries where they have a lower cost of production per unit.

It is believed that foreign companies make better use in practice of management and advanced technologies that lead to a healthier environment in the host country. However, in practice, trends in environmental protection by foreign companies have proved unsustainable. Empirical evidence shows just that, especially in energy-intensive and technology-based sectors. Economic growth through rapid industrialization is also conditioned by growing environmental consequences. The connection between the quality of the environment and economic development has provoked a heated debate in the last decade.

Empirical studies have also supported this relationship between environmental degradation and economic growth. "8 The

\footnotetext{
6 Olgica Nestorović, Foreign direct investment as a factor of sustainable development of the Serbian economy, Faculty of Economics in Kragujevac, University of Kragujevac, 2015, pages 70-96

${ }^{7}$ Finkelstein, J.,(1991) Capitalism and Technology, The World \&I (November)
}

This publication is licensed under Creative Commons Attribution CC BY

http://dx.doi.org/10.29322/IJSRP.11.12.2021.p12051
Rio summit introduced radical changes and had a decisive impact on changing the model of financing sustainable development. This statement is confirmed by the three key changes in financing sustainable development that have taken place since the Summit.

The first novelty refers to the introduction of new instruments in environmental policy both at the national and international level. At the national level, there are noticeable efforts to reduce the use of environmentally inefficient subsidies in environmental policy and the introduction of environmental costs, environmental fees (user fees) and emission trading programs. On the international stage, private companies and governments of some countries have initiated pilot programs on joint activities and signed biodiversity agreements. Since developing countries have an abundance of natural resources and a lack of capital, the prevailing belief is that such international mechanisms will encourage the transfer of significant flows of financial resources and technologies, from developed to underdeveloped countries.

The second, in order to steer the economies of developing countries on the path to sustainable development, Agenda 21 commits \$ 125 billion a year in new and additional financial resources to be transferred to these countries. It is estimated that after the summit in Rio, more than 125 billion US dollars a year were transferred from developed developing countries, not from public, but from private sources. Official development assistance and efforts to mobilize domestic resources have shown shortcomings in meeting commitments set at the Rio summit. Funds earmarked for global environmental relief and the Montreal Protocol Multilateral Fund have been increased, but not to the extent expected. Many developing countries have increased investment in the social and environmental sectors, in some cases through the establishment of extra-budgetary environmental funds, as well as through traditional budget allocation mechanisms.

The third, after Rio Summit, there has been a sharp increase in private capital flows to finance sustainable development from developed to developing countries. Foreign private capital became the dominant source of capital for many developing countries during the 1990s. Private capital flows accounted for only one-third of total capital flows to developing countries during the 1980s. Motivated by the possibility of making high profits, private capital flows will continue their further expansion, thanks to the continuous process of globalization of production, trade liberalization and financial integration.

Private capital flows, motivated more by opportunities to conquer new markets and maximize profits than by the need for additional capital or development priorities of the host country, avoiding poor countries, riskier for investment, with underdeveloped institutions and poor infrastructure. In addition, the essential characteristic of private capital flows is their variability and high degree of sensitivity to changes in market conditions. "9

8 Rothman, D.S. (1998) „Environmental Kuznets curve - real progress or passing the buck?: A case for consumption-base approaches, Ecological Economics, 25 p.186

9 Olgica Nestorović, Foreign direct investment as a factor of sustainable development of the Serbian economy, Faculty of 
Each state should, within its environmental policy, take into account on the one hand the protection of the environment, and on the other hand, the provision of economic growth of the country, ie to control the ecological balance while strengthening the dynamics of economic development. The main procedures of environmental policy are reflected in the following:

- "harmonization of economic development with the needs for preserving the ecological balance,

- $\quad$ acting in the direction of creating new needs that are in accordance with the principles of environmental safety,

- focus in the application and commercial valorization of those main directions of modern scientific and technical progress that are maximally in the function of meeting increasingly stringent environmental standards,

- $\quad$ conducting an appropriate demographic policy.

In the context of the environmental dimension, it is a policy that seeks to ensure population growth that can seamlessly support existing economic growth and the current development of science and technology. "10

\section{CONCLUSION}

Finally, it is necessary to find new values of sustainable development in the field of environment, as well as the creation and preservation of the so-called. green values through the development of new, ecologically cleaner industrial parks, zones and regions. "Such values include environmental management, thrift and resource adequacy, fairness and adequacy in relation to society and accountability. Although the path to environmental competitiveness as an advantage is a difficult path that requires time, effort and money, the reward may be in reducing the negative impact on the end result in the short term. The proactive thinking of management dealing with environmental protection and preservation will set the standards for greater overall business performance.

The main goal of the proactive environmental strategy is to obtain a sustainable competitive advantage that refers both to the market and to the reduction of investment costs incurred by the application of new standards and environmental protection by large, small and medium enterprises. The development and implementation of an environmental strategy, in a proactive way, is, however, an extremely difficult process, involving not only leaders in the field of environmental protection and preservation, but also significant resources and long-term strategies. Effective implementation of proactive environmental strategies requires a knowledge-based economy, which usually involves significant financial effort.

Only highly developed countries can meet these requirements, and the construction of incinerators in countries in transition is just an attempt to transfer dirty technology to a location where the costs of environmental protection are lower. As the decision on the inflow of foreign direct investment can have a wider economic, political, social and environmental impact than the local level, it is necessary to ensure the active role of public opinion and the professional public in decision-making. is in marketing strategies, as an integral part of the company's image.

\section{AUTHORS}

First Author - Auob Alsayd Phd. candidate
Economics in Kragujevac, University of Kragujevac, 2015, pages 98-99
${ }^{10}$ Cvetanović, S. Jovović, D., (2006) Economic policy of the European Union - new European economy, Faculty of Economics, Niš, 2006, p. 192. 